\title{
Risk Mapping of Coastal Flooding Areas. Case Studies: Scilla and Monasterace (Italy)
}

\author{
Giuseppe Barbaro, Giandomenico Foti ${ }^{*}$, Antonella Nucera, Giuseppina Chiara Barillà, Caterina Canale, Pierfabrizio Puntorieri,
} Francesca Minniti

\author{
Mediterranea University of Reggio Calabria (Italy), DICEAM Department, Via Graziella, loc. Feo di Vito, 89122 - Reggio \\ Calabria, Italy
}

Corresponding Author Email: giandomenico.foti@unirc.it

https://doi.org/10.18280/ijsse.100108

Received: 18 January 2019

Accepted: 1 November 2019

\section{Keywords:}

coastal flooding, coastal flooding areas,

damage, hazard, mapping, risk

\begin{abstract}
Coastal flooding is a danger to people who live near coasts. It is therefore necessary to increase knowledge of the causes of coastal flooding through scientific research. Furthermore, the correct assessment of flooding areas is very important for the management of coastal areas. Given this, the current European legislation (Directive 2007/60/EC) requires flood areas to be mapped, but to date in Italy each region is still adopting different procedures to map their flood areas. This paper, through two case studies, analyzes the hazard, damage and risk mapping of coastal flooding areas. The cases are related to two Calabrian towns, located along the Ionian coast (Monasterace), and the Tyrrhenian coast (Scilla), with both particularly prone to coastal flooding. In particular, with regards to the hazard mapping, the effects of sea storms and climate changes were taken into account. The damage assessment followed an "ex ante" approach, based on the employment of land use maps, in accordance with current Italian legislation. Furthermore, risk maps were added, and obtained by combining both damage and hazard maps. Finally, a comparison with previous events allowed us to verify the validity of the proposed methodology.
\end{abstract}

\section{INTRODUCTION}

Coastal flooding is a danger to people who live near coasts, which currently represent about a third of the world's population $[1,2]$. To analyze coastal flooding, it is necessary to know the coastal dynamics and the factors that influence it, which can be mainly grouped in natural and anthropic factors [3-6]. These factors have increased the vulnerability of coastal areas to natural events [7-12]. Regarding the anthropic factors, the most important are the construction of infrastructures, ports and coastal defense works [13-15]. Amongst the natural factors, wave action and longshore and river transport are of particular importance [16-25].

Until recently, most of the legislations and of the scientific research focused only on river and urban flooding or coastal erosion [26-29] but in the last 15 years the coastal flooding risk has significantly increased due to climate changes which have caused an increase in the sea level, and in the frequency of extreme events. As a consequence, in recent years, scientific researchers and legislators have devoted more attention to coastal flooding [30-39].

Damage estimation in general is very important for the evaluation of mitigation measures, which may be structural or non-structural (such as alert systems, insurance policies etc.). Moreover, damage estimation is important for the planning, management and protection of coastal areas [40-43].

Damage can be tangible or intangible. Tangible damages can be assigned a monetary value whereas intangible damages cannot be economically quantified [44]. The damage depends on two types of factors: some of these are related to the characteristics of the area at risk, such as land use and its vulnerability, and the other factors are related to the characteristics of the natural event. In particular, for coastal flooding, the main characteristics of the event are flooding height and duration, water speed and water sediment content [45].

Flood damage can be assessed following two different approaches, depending on the assessment purpose [46]. The first approach is called "ex ante", or "potential damage", and performs an assessment of potential damage related to design scenarios. The second approach is called "ex post", or "real damage", and is an assessment of the damage related to real events. However, the latter approach is difficult to apply due to the difficulty in obtaining historic damage information and in estimating its monetary value in a consistent manner. Therefore, in recent years the "ex ante" approach has been widely used because it does not require information on real events and is applicable in any context, even in areas where floods have never occurred. The methods for damage assessment vary from different country and they are almost all in the validation phase [47].

In Italy, the method used for damage assessment is described in Legislative Decree No. 49/2010, which is based on Current European legislation, Flood Directive 2007/60/EC $[48,49]$. In fact, this requires the assessment of flood risk in coastal and rivers areas, the mapping of the floodable areas and the evaluation of the elements at risk in these areas. The assessment concerns the potential damage, defined as the predictable degree of loss, following a natural phenomenon of given intensity. The potential damage is a function of both the value and the vulnerability of the exposed element. Assuming that the damage level of each exposed element is maximum in all the mapping areas (i.e. that the vulnerability has the same value and it is equal to 1 ), it follows that the potential damage 
maps coincide with the exposed elements maps. For this reason, in a first phase of risk mapping, it is possible to employ land use maps, from which the potential damage maps are derived.

This paper, following the study of Nucera et al. [50], analyzes the hazard, damage and risk mapping of coastal flooding areas through two case studies. These case studies are related to two Calabrian towns, located along the Ionian (Monasterace), and Tyrrhenian (Scilla) coasts and both are particularly prone to coastal flooding. In particular, for the hazard mapping, the effects of sea storms and climate changes were taken into account. The damage assessment followed an "ex ante" approach, based on the employment of land use maps, in accordance with the current Italian legislation. Risk maps were added, obtained by combining damage and hazard maps.

Therefore, the paper applies existing methodologies to map the hazard, damage and risk areas of two locations particularly prone to coastal flooding. Furthermore, the comparison with previous events allowed us to verify the validity of these methodologies.

Compared to the paper by Nucera et al. [50], in this paper the approach to the problem of coastal flood mapping has changed. In fact, in the previous paper the sea storms that previously occurred in the study areas were analyzed, in order to identify the damage curves. In this paper, on the other hand, the objective was centered on coastal flood mapping. Therefore, for each storm a hazard class, which depends on the return period, and a damage class, which is congruent with the Flood Directive 2007/60/EC, were assigned. Another change, compared to Nucera et al. paper, concerned the updating of the calculation of the location characteristic parameters using a Matlab code in order to improve the accuracy of the calculation of the significant heights of a fixed return period. Furthermore, compared to the Nucera et al. paper, the run-up estimation phase was modified, taking into account only the Stockdon et al. model [51], in accordance with the Floos Directive, and taking into account the new location characteristic parameters.

Finally, compared to the previous paper, the hazard maps, taking into account both the new run-up values and the sea level rise still in progress, and the damage maps, as described above, were also updated. Furthermore, risk maps have been added, which were obtained by combining hazard and damage maps.

\section{DESCRIPTION OF THE CASE STUDIES}

\subsection{Description of Scilla}

The first case study is related to Scilla, a town located in the southern part of the Calabria region, near the Messina Strait (Figure 1). The territory of Scilla is compressed between sea and mountain and the town is divided into three sections, one near a pocket beach (called Marina Grande), one on a hill not far from the beach, and one near the port (called Chianalea), with houses built close to the sea, and which has no beach (Figure 2). The site is affected by the prevalent winds that blow from North and North-Westerly directions and is often subject to hydrogeological instability phenomena because of the orographic effect caused by the nearby mountains. In particular, the frequent storms coming from the North and North-Westerly directions reach high heights, such as to completely flood the beach and to reach the houses upstream of the beach promenade (Figure 2). From the climatic point of view, the study area is of Mediterranean warm temperature (according to the Koppen classification), with both mild autumns and winters and long and dry springs and summers.

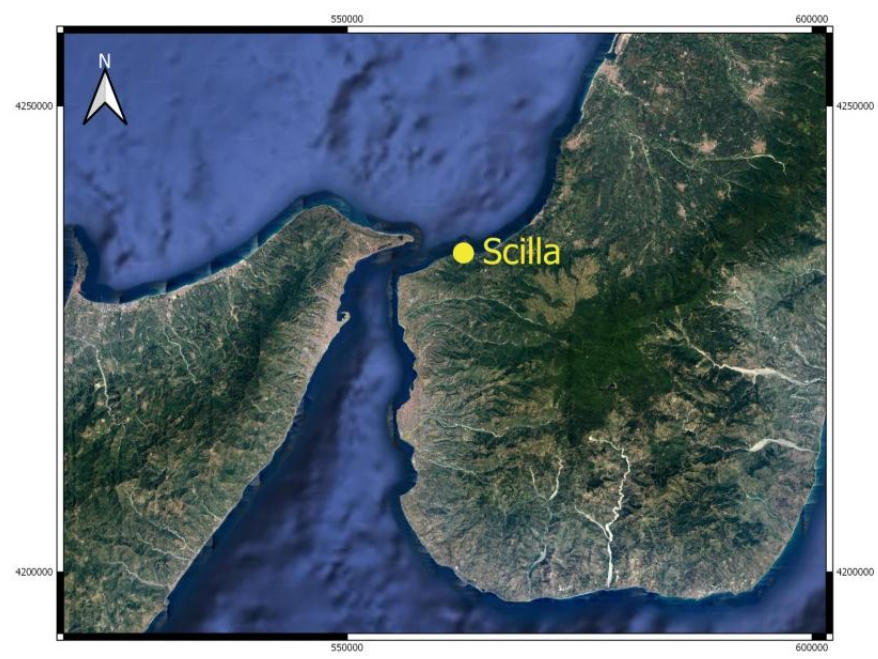

Figure 1. Location of Scilla

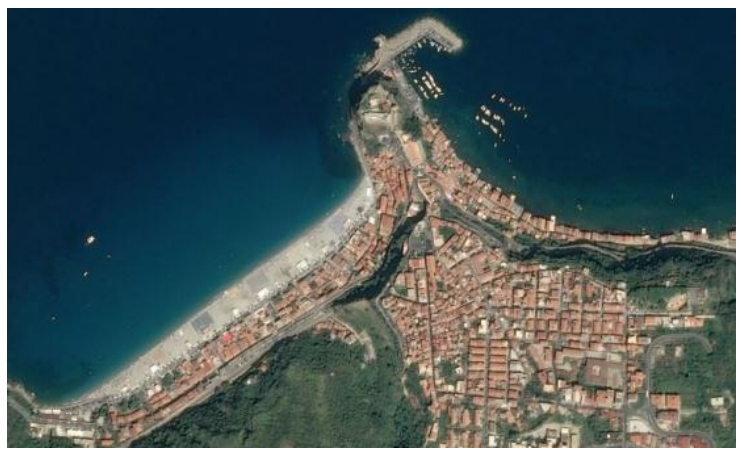

(a) The pocket beach and the Marina Grande locality, the port and the Chianalea locality (source: Bing Maps)

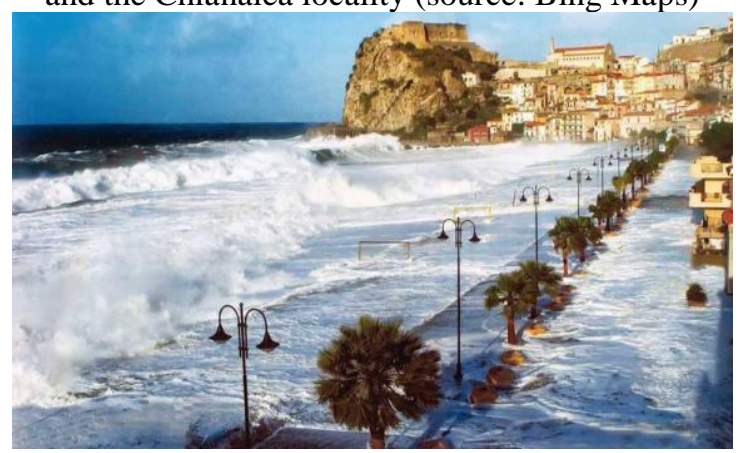

(b) Coastal flooding in Marina Grande

Figure 2. Scilla

\subsection{Monasterace description}

The second case study is related to Monasterace, a town located on the Ionian coast of Calabria (Figure 3). The town is located between the mouth of two rivers and is affected by the prevalent winds that blow from the South, South East and North Easterly directions. The most severe storms come from the South Easterly directions, where the fetch is up to $700 \mathrm{~km}$, and they are concentrated in the winter season. Near the town there is an archaeological site that extends along the coast on a sand dune for $1 \mathrm{~km}$, and which consists of an ancient town, 
a Doric Temple and a Pillbox (Figure 4). In the last 20 years, the beach in front of the dune is eroding and the storm frequently reaches the dune, causing the erosion of the dune and damage to the archaeological site.

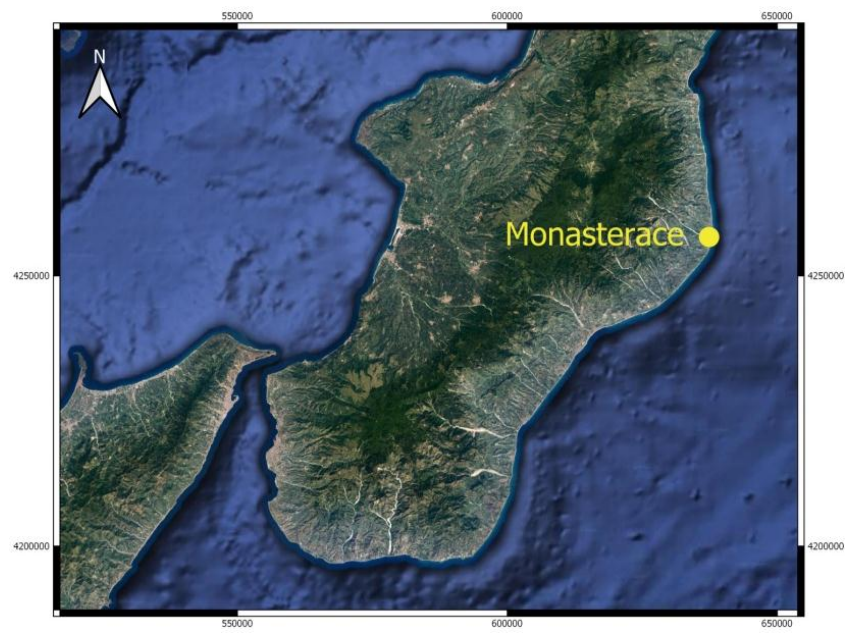

Figure 3. Location of Monasterace

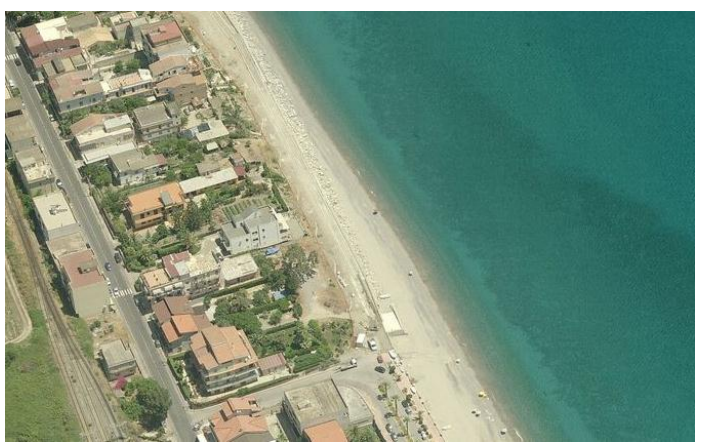

(a) The promenade

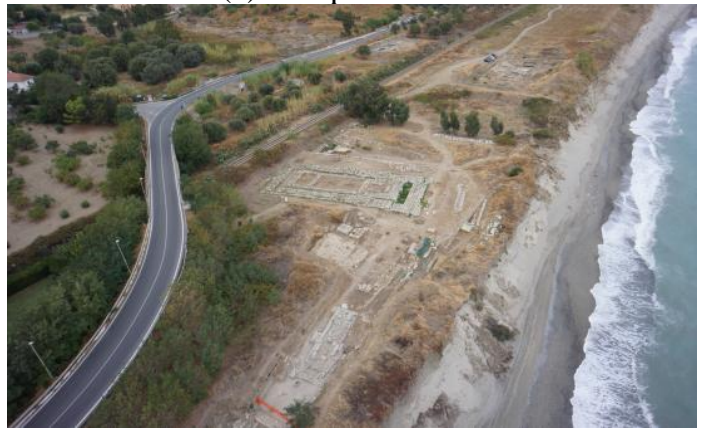

(b) The archaeological site (source: Bing Maps)

Figure 4. Monasterace

\section{METHODOLOGY}

The methodology used to estimate the levels of hazard, damage, and therefore, risk is derived from the intersection of different methods and normative requirements. In particular, data analysis, statistical elaborations, study of real events and the use of normative guides on a national and international scale were intertwined.

Regarding the hazard mapping, the effects of sea storms and of climate changes were taken into account. The damage assessment followed an "ex ante" approach, based on the employment of land use maps, in accordance with current Italian legislation. Two databases were consulted for this purpose. The first database was developed by the University of Genoa, in particular the MeteOcean group. This database contains wave data from the last 40 years, in particular for the period 1979-2017. This data was reconstructed from the Climate Forecast System Reanalysis (CFSR) database. The analysis of the data provided by this database has allowed us to estimate the hazard levels, as described below, and to identify the storms, according to the Boccotti's theory [52], which are mentioned as dangerous events in the second database.

The second database was developed by the CNR-IRPI (National Research Council, Research Institute for Hydrogeological Protection) of Cosenza and is called A.Si.Cal. (Historically flooded areas in Calabria). This database contains information about hydrogeological instability events that have occurred in Calabria in the last few centuries. These events include sea storms and, for each event, information about the date and the damage generated by the event are available. This database was used to identify and classify actual events and their relative recorded damage in order to verify the validity of the methodologies used in this paper.

Before mapping the coastal flooding hazard, it was necessary to analyze the characteristics of the storms which occurred in the two locations mentioned above.

For each location, the data provided by the MeteOcean group was statistically processed: this analysis allowed us to determine the parameters ( $\mathrm{u}$ and $\mathrm{w}$ ) that describe a Weibulltype distribution of the probability of exceeding a fixed significant height threshold [52]; using a matlab code, the values of $a_{10}$ and $b_{10}$ of both locations were obtained, where they represent the average values of triangular storm heights and bases equivalent to the real storms, respectively, referring to a sample of the $\mathrm{N}$ stronger real storm, with $\mathrm{N}$ equal to 10 for the number of years of registration.

The estimation of these parameters, which are characteristic of the analyzed location, allowed us to assess the significant height of fixed return period. With regard to the choice of hazard levels, after a preliminary and careful analysis of the normative requirements and of the methodologies used on a regional scale, the choice of the three hazard levels as 1, 20 and 100 years was made. For each return period, the significant height and the run-up were calculated. Regarding the run-up, this was estimated using the Stockdon et al. model [51] and the results were compared with the events in the A.Si.Cal. database to verify the correspondence of the model results with previous events.

The maximum tidal excursion and the sea level rise were added to the run-up values obtained. To estimate the tidal excursions, the data recorded by the National Tidal Network gauges were analyzed. The two locations studied are without gauges so it was necessary to analyze the data recorded by the two nearest gauges. In particular, to obtain the tidal excursion values of Scilla, data from the Reggio Calabria gauges were analyzed, while data from the Crotone gauge was analyzed to obtain the tidal excursion values for Monasterace. Regarding the sea level rise, recent scientific research was analyzed and the results are discussed in the next section.

Then, after estimating wave run-ups, maximum tidal excursions and the sea water level rise for both locations, coastal flooding hazard maps were drawn up for 3 different scenarios, corresponding to storms with a return period of 1 , 
20 and 100 years respectively.

The hazard maps were plotted by comparing the digital elevations of the land, obtained from the LIDAR data with a square mesh of $1 \mathrm{~m}$ available in the Italian National Geoportal (http://www.pcn.minambiente.it/mattm/), with the run-up values reached by the storms of fixed return period, inclusive of the tidal excursion and of the sea water level rise (SWLR). In this way, all areas with elevations below the wave rise for the three return periods were mapped, thus obtaining the hazard mapping.

Moreover, in order to verify the validity of the methodologies used in this paper, the actual events and their relative recorded damage present in the A.Si.Cal. database were classified. For this purpose, Boccotti's theory [52] was used to identify each storm present in the time series. This criterion identifies a critical threshold, equal to 1.5 times the significant average height of the entire time series, and defines as a sea storm any event in which the recorded significant height exceeds this threshold. After identifying all the storms present in the time series provided by MeteOcean group, only those also present in the A.Si.Cal. database were analyzed in detail. Finally, the maximum significant wave height, the storm duration and the hazard level were estimated for each of these storms.

From the two databases described above, 21 events were identified for Scilla (Table 1) and 17 for Monasterace (Table 2), excluding events for which the information on the effects was not available.

The classification of the potential damage class was made by analyzing the land use, assuming that the damage level of each exposed element was the maximum in all the mapping areas. Therefore, regarding the damage maps, the input data was that available in the OpenData section of the Calabrian Geoportal (http://geoportale.regione.calabria.it/). In particular, the shapefiles of the land use were analyzed and the potential damage classes, from D1 to D4 to increasing damage, were in agreement with the Flood Directive 2007/60/EC. These classes depend mainly on damage to people, and then to socioeconomic and non-monetizable assets. In particular, the D4 class includes areas in which loss of human lives, huge damage to natural, historical, cultural and economic assets and environmental disasters can occur. The shapefiles of infrastructures, urban and industrial settlements, monuments and archaeological sites, parks and sites of interest were therefore considered for the D4 class. The D3 class includes areas with problems for the safety of people and areas with primary communication infrastructures and important production activities, such as mining areas, landfills and oases and reserves. On the other hand, areas with secondary communication infrastructures and minor production activities fall within class D2. The shapefiles of woods, citrus groves, orchards, vineyards, olive groves and rural settlements were therefore considered for the D2 class. Finally, the D1 class includes areas without urban or productive settlements, such as beaches and dunes, lagoons and lakes, waterways, natural pasture areas and grasslands. The damage maps obtained show that the flooding areas are characterized by D1 and D4 classes of potential damage both in Scilla and in Monasterace.

Finally, risk maps were obtained by overlapping the hazard and damage maps, according to the matrix described in Table 3.

Table 1. Storms of Scilla

\begin{tabular}{|c|c|c|c|c|c|}
\hline Event date & $H_{s, \max }[\mathrm{m}]$ & $\Delta \mathrm{t}[\mathrm{h}]$ & Haz. level & Summary description of damages & Dam. leve \\
\hline Jan 1979 & 4.2 & 96 & P3 & Residents evacuation, flooded homes, damage to citrus groves. & D4 \\
\hline $\begin{array}{l}\text { Dec 1979/ } \\
\text { Jan } 1980\end{array}$ & 6.7 & 154 & P2 & $\begin{array}{l}\text { Wounded. Residents evacuation. Damage to homes, water and sewage } \\
\text { networks, tennis courts, shops, restaurants, bars, church. Roads invaded by } \\
\text { mud and debris. Downed } 50 \text { meters of a breakwater pier and sunken boats. }\end{array}$ & D4 \\
\hline Jan 1981 & 4.8 & 221 & P2 & $\begin{array}{l}\text { Evacuated residents, homes and public premises flooded and invaded by } \\
\text { debris, flooded citrus groves. }\end{array}$ & D4 \\
\hline Oct 1982 & 1.34 & 13 & P3 & Damage to homes, roads, sewers. & D4 \\
\hline Feb 1983 & 5.6 & 48 & P2 & Damage to houses, roads, citrus groves. & D4 \\
\hline Jan 1984 & 1.57 & 48 & P3 & Interruption of railway traffic. & D4 \\
\hline Feb 1984 & 4.64 & 149 & P2 & Damage to the port. & D4 \\
\hline Dec 1984 & 1.30 & 54 & P3 & $\begin{array}{l}\text { Damage to maritime structures, undermining of the embankment walls } \\
\text { and rebels of the Favazzina torrent. }\end{array}$ & D4 \\
\hline Jan 1985 & 2.24 & 133 & P3 & Flooded Chianalea dwellings. & D4 \\
\hline Jan 1986 & 3.33 & 57 & P3 & Damage to homes, roads and port. & D4 \\
\hline Dec 1986 & 3.83 & 162 & P3 & Flooded streets. & D4 \\
\hline Feb 1990 & 3.77 & 120 & P3 & Damage to coastline, road infrastructure and sewage network. & D4 \\
\hline Nov 1991 & 6.2 & 125 & P2 & Damage to roads, invaded by debris, sewage system and lighting. & D4 \\
\hline Jan 1993 & 2.28 & 54 & P3 & Damage to maritime structures. & D4 \\
\hline Dec 1999 & 4.03 & 97 & P3 & $\begin{array}{l}\text { Flooded dwellings. Damage to roads, street furniture and lighting, water } \\
\text { supply and sewers (clogged with sand and debris), port. }\end{array}$ & $\mathrm{D} 4$ \\
\hline Feb 2007 & 4.35 & 40 & $\mathrm{P} 2$ & $\begin{array}{l}\text { Damage to houses and restaurants, evacuated inhabitants. Damage to } \\
\text { roads and traffic interruptions. }\end{array}$ & D4 \\
\hline Dec 2012 & 3.67 & 225 & $\mathrm{P} 3$ & $\begin{array}{l}\text { Damage to roads, street furniture, boats, port. Damage to public } \\
\text { infrastructure, traffic, private facilities, production activities, homes. }\end{array}$ & D4 \\
\hline Mar 2013 & 2 & 104 & P3 & Road traffic interruption. & D4 \\
\hline Nov 2013 & 1.89 & 46 & P3 & Deposit of debris on the seafront. & D4 \\
\hline Feb 2015 & 3.9 & 70 & P3 & Damage to boats. & D4 \\
\hline Oct 2015 & 2.46 & 66 & P3 & Damage to boats. & D4 \\
\hline
\end{tabular}


Table 2. Storms of Monasterace

\begin{tabular}{|c|c|c|c|c|c|}
\hline Event date & $\mathbf{H}_{\mathrm{s}, \max }[\mathbf{m}]$ & $\Delta \mathbf{t}[\mathbf{h}]$ & Haz. level & Summary description of damages & Dam. level \\
\hline Jan 1985 & 6.08 & 65 & P2 & Damage to the waterfront. & D4 \\
\hline Dec 1990 & 3.14 & 46 & P3 & Damage to coastal defense structures. & D4 \\
\hline Nov 1991 & 5.57 & 42 & $\mathrm{P} 2$ & Damage to roads and waterfront. & D4 \\
\hline Jan 1993 & 5.1 & 78 & $\mathrm{P} 2$ & Damage to roads, waterfront, bathing facilities, sewage system. & D4 \\
\hline Dec 1993 & 2.4 & 68 & P3 & Damage to the waterfront. & D4 \\
\hline Feb 1994 & 4.35 & 82 & $\mathrm{P} 2$ & Damage to the road, waterfront, water, sewage and electrical systems. & D4 \\
\hline Feb 1994 & 3.83 & 85 & P3 & Damage to waterfront, road, water, sewage and lighting systems. & D4 \\
\hline Nov 1994 & 3.12 & 43 & P3 & Erosion. & D4 \\
\hline Jan 1996 & 3.41 & 180 & $\mathrm{P} 3$ & Erosion, damage to roads and waterfront. & D4 \\
\hline Jan 1996 & 3.01 & 94 & $\mathrm{P} 3$ & Damage to the waterfront, evacuated inhabitants. & D4 \\
\hline Feb 1996 & 4.1 & 72 & P3 & Damage to the waterfront, evacuated inhabitants. & D4 \\
\hline Mar 1998 & 6.1 & 91 & $\mathrm{P} 2$ & Damage to homes, buildings, waterfront and boat. & D4 \\
\hline Jan 2010 & 5.28 & 60 & $\mathrm{P} 2$ & Damage to the archaeological area. & D4 \\
\hline Feb 2012 & 5.48 & 84 & $\mathrm{P} 2$ & Roads flooded and invaded by sand and debris, broken roads. & D4 \\
\hline Dec 2013 & 5.21 & 75 & $\mathrm{P} 2$ & Damage to the archaeological site. & D4 \\
\hline Feb 2014 & 5.61 & 140 & $\mathrm{P} 2$ & $\begin{array}{c}\text { Damage to the archaeological site, threatened houses, damage to roads, } \\
\text { waterfront, traffic (sand and debris). }\end{array}$ & D4 \\
\hline $\begin{array}{l}\text { Oct }- \text { Nov } \\
2015\end{array}$ & 5.38 & 96 & $\mathrm{P} 2$ & $\begin{array}{l}\text { Damages to the waterfront, roads, and to the dune to protect the } \\
\text { archaeological site. }\end{array}$ & D4 \\
\hline
\end{tabular}

Table 3. Risk matrix

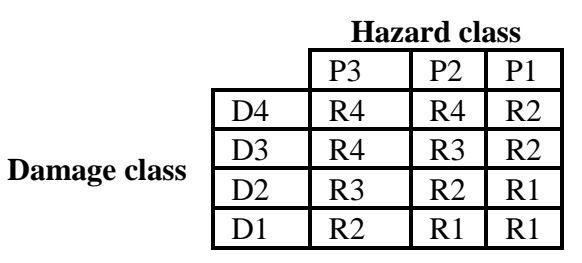

\section{RESULTS AND DISCUSSION}

In this section, the values of the wave parameters will be presented first, then the hazard, damage and risk maps will be analyzed.

The first parameter analyzed was the significant wave height of fixed return period. In Scilla the values are about 4.5 $\mathrm{m}, 7.3 \mathrm{~m}$ and $8.8 \mathrm{~m}$ for return periods of 1,20 and 100 years respectively. In Monasterace, on the other hand, these values are about $4.2 \mathrm{~m}, 6.3 \mathrm{~m}$ and $7.4 \mathrm{~m}$ for the same return periods.

Regarding the run-up, in Scilla the values are about $3.1 \mathrm{~m}$, $5 \mathrm{~m}$ and $6.1 \mathrm{~m}$ for return periods of 1,20 and 100 years respectively. In Monasterace, on the other hand, these values are about $1.8 \mathrm{~m}, 2.6 \mathrm{~m}$ and $3.1 \mathrm{~m}$ for the same return periods.

Regarding the tidal excursion, over 350,000 data items are available for each gauge mentioned above. The tidal excursion obtained in Scilla is greater than $20 \mathrm{~cm}$ while the variation in Monasterace is slightly less than $50 \mathrm{~cm}$. In both cases these are low values, but are still in line with the results obtained by Sannino et al. [53].

Regarding the sea level rise, Nerem et al. [54] estimated that the average sea level has increased by $7 \mathrm{~cm}$ over the past 25 years and they shown that the growth rate is non-linear (previously it was about $3 \mathrm{~mm} /$ year), but is accelerated by $0.084 \mathrm{~mm} /$ year. These results were obtained using data from 1993 to date from various satellites such as TOPEX/Poseidon, Jason-1, Jason-2 and Jason-3 and they are in accordance with the forecasts described in the fifth IPCC Report [55]. Therefore, the average value is expected to be about $10 \mathrm{~cm}$, in the next 20 years, and about $80 \mathrm{~cm}$ in the next 100 years.
Therefore, the hazard has been mapped taking into account the sum of the run-up values, tidal excursion and sea level rise. In detail, the values obtained in Scilla are about $3.4 \mathrm{~m}, 5.4 \mathrm{~m}$ and $7.1 \mathrm{~m}$ for return periods of 1,20 and 100 years respectively. In Monasterace, on the other hand, these values are about 2.2 $\mathrm{m}, 3.2 \mathrm{~m}$ and $4.3 \mathrm{~m}$ for the same return periods.

Regarding the hazard mapping, Figure 5 shows that in Scilla the port and numerous houses located in Chianalea are flooded annually. However, in Marina Grande only the beach floods annually, and is almost completely flooded on the western side and partially flooded in the remaining areas. The promenade of Marina Grande and its houses are flooded from events with a return period of 20 years whilst events with a return period of 100 years flood the whole town. In Monasterace, as shown in Figure 6, only the floods with events with a return period of 100 years reach the promenade and the houses. The floods with the shorter return period affect only the beach and the foot of the dune on which the archaeological site is located.

With reference to damage maps, as shown in Figures 7 and 8 , in both locations the flood areas fall into damage classes D1 and D4. In the D1 class the beaches are included in the damage areas, while in the D4 class there are houses, promenades, state roads, the port of Scilla and the archaeological site of Monasterace.

Finally, concerning the damage maps, Figures 9 and 10 and Tables 4 and 5 show that in Scilla an area of over 115,000 $\mathrm{m}^{2}$ is at risk. Most of it falls into the R2 class, with over 56,000 $\mathrm{m}^{2}$, and the R4 class of about $42,000 \mathrm{~m}^{2}$, while the remaining part falls into the R1 class. Moreover, almost 200 houses are at risk, 105 of which are in class R2 with the rest falling into the R4 class. In addition to the houses, 10 bathing establishments are also at risk, the entire promenade, the road connecting the promenade and the port and a part of the state road, for a total road length of over $1 \mathrm{~km}$, most of which is included in R4 class. In Monasterace on the other hand, the area at risk is about $65,000 \mathrm{~m}^{2}$, of which about $45,000 \mathrm{~m}^{2}$ are classified as R2 and the remaining part as R1. In addition, 31 houses and a part of the promenade are also at risk, for a road length of about $650 \mathrm{~m}$. 


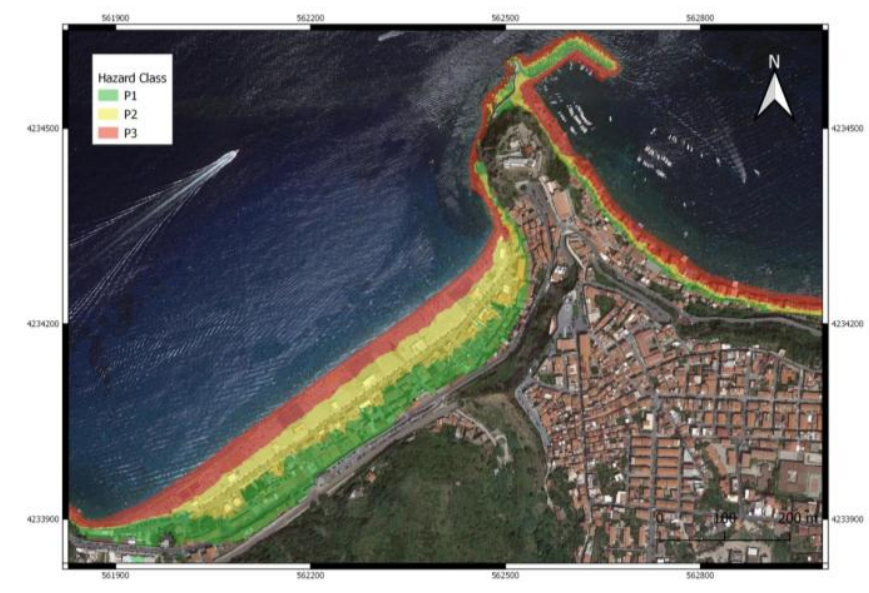

Figure 5. Coastal flooding hazard map of Scilla

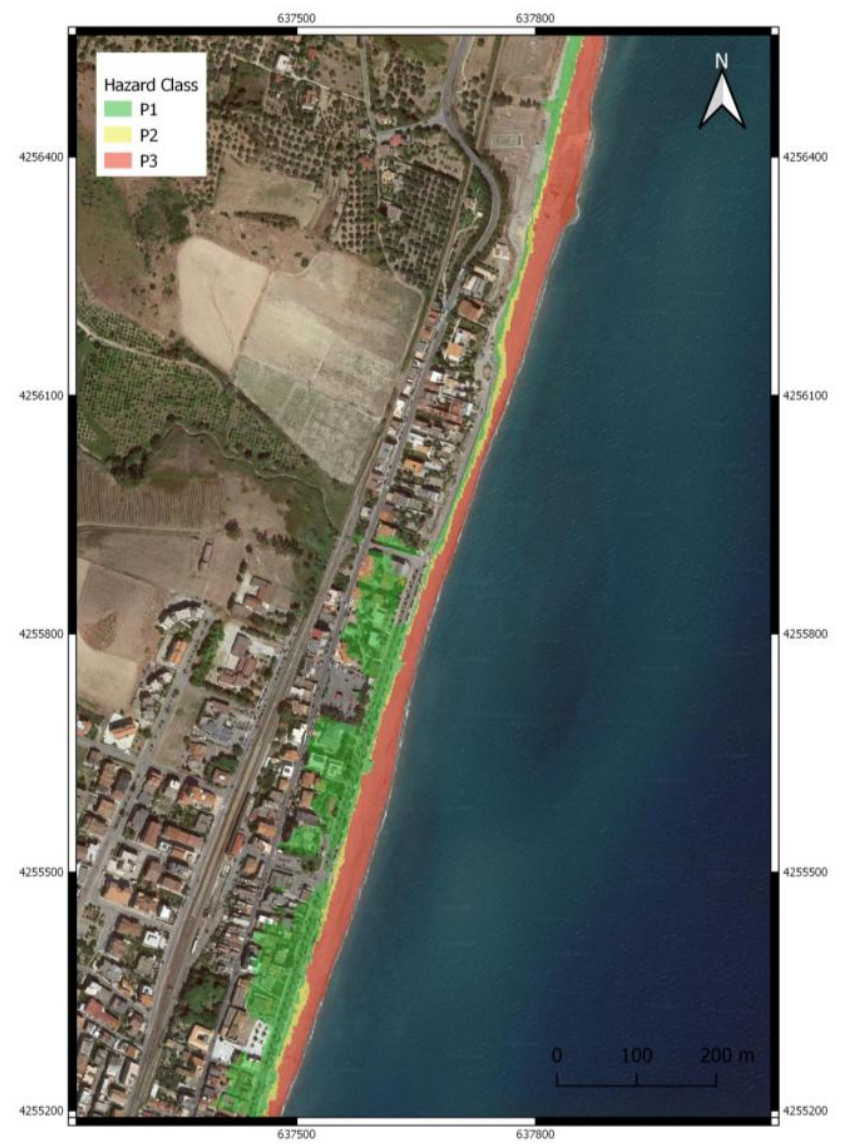

Figure 6. Coastal flooding hazard map of Monasterace

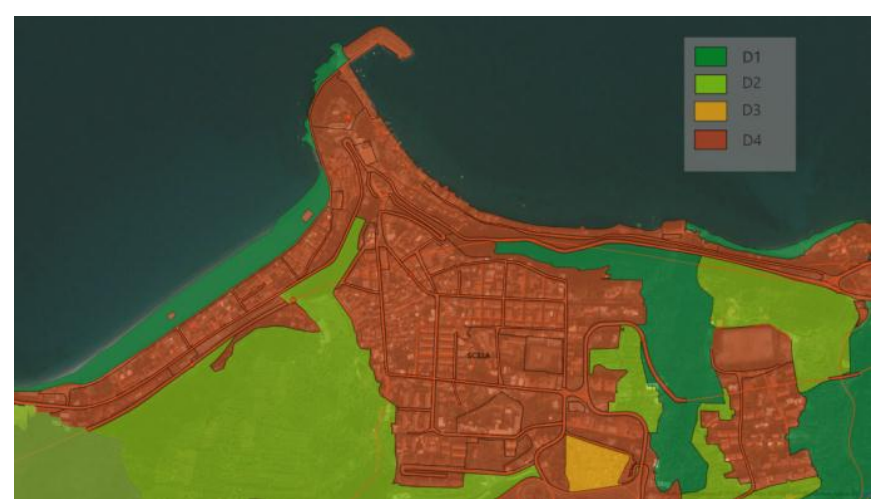

Figure 7. Coastal flooding damage map of Scilla

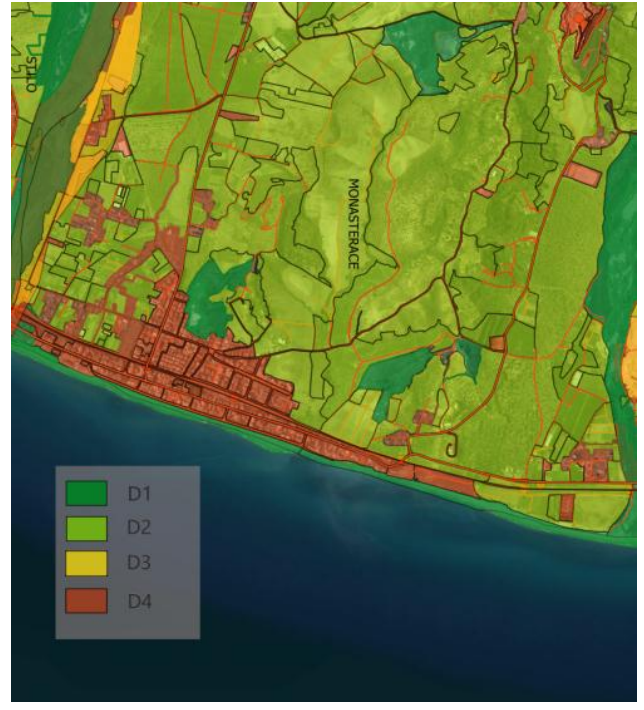

Figure 8. Coastal flooding damage map of Monasterace

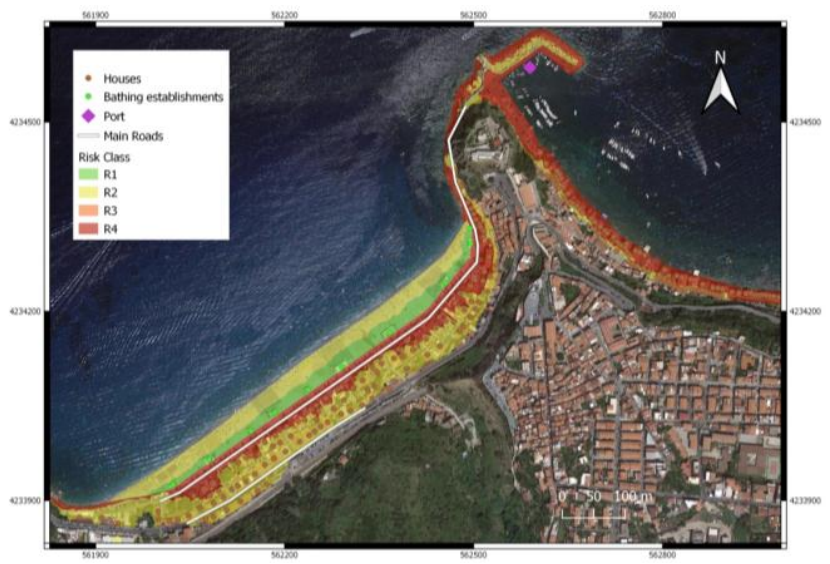

Figure 9. Coastal flooding risk map of Scilla

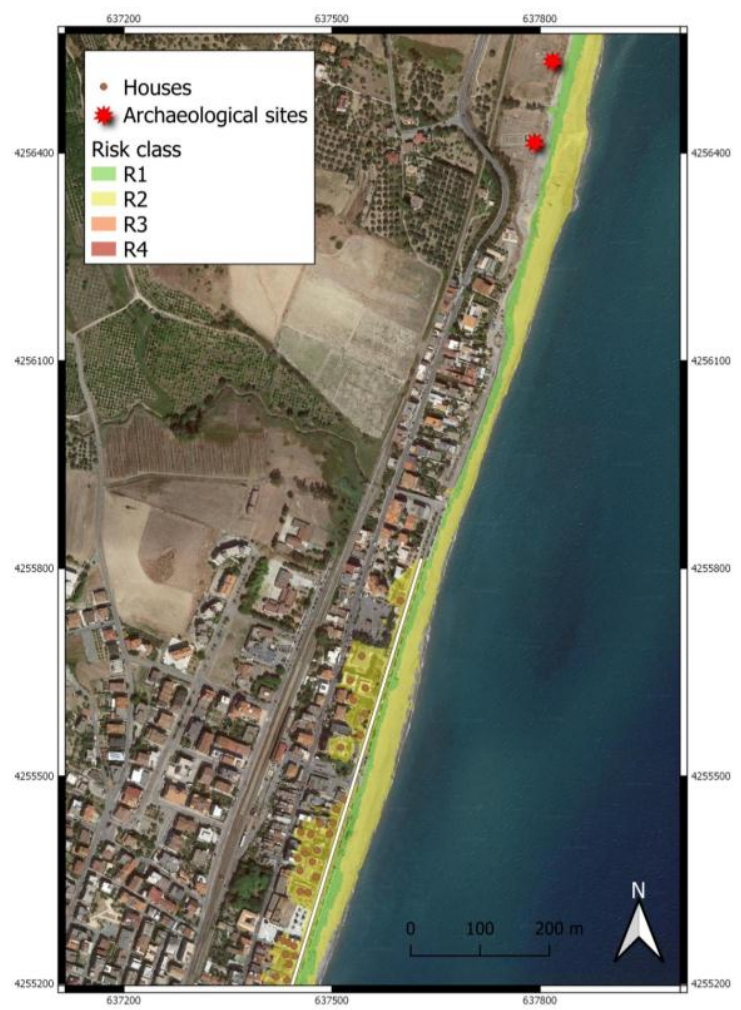

Figure 10. Coastal flooding risk map of Monasterace 
Table 4. Areas and elements at risk in Scilla

\begin{tabular}{cccc}
\hline Scilla & R1 & R2 & R4 \\
\hline Area $\left[\mathrm{m}^{2}\right]$ & $11,848.4$ & $56,032.2$ & $41,792.4$ \\
Houses & 0 & 105 & 86 \\
Bathing establishments & 10 & 0 & 0 \\
Roads length [m] & 0 & 365.24 & 865.36 \\
\hline
\end{tabular}

Table 5. Areas and elements at risk in Monasterace

\begin{tabular}{ccc}
\hline Scilla & R1 & R2 \\
\hline Area $\left[\mathrm{m}^{2}\right]$ & $20,471.1$ & $44,402.7$ \\
Houses & 0 & 31 \\
Roads length $[\mathrm{m}]$ & 0 & 645 \\
\hline
\end{tabular}

\section{CONCLUSIONS}

The paper, through two case studies, analyzes the hazard, damage and risk mapping of coastal flooding areas. These cases are related to two Calabrian towns located along the Ionian (Monasterace), and Tyrrhenian (Scilla) coasts and both are particularly prone to coastal flooding.

The hazard, damage and risk mapping of coastal flooding areas were preceded by an analysis of the storms that affected the two locations studied. This analysis was conducted using data present in two databases, one containing hydrogeological instability events which occurred in Calabria in the last few centuries, and the other containing wave data for the period 1979-2017.

The hazard maps were plotted by comparing the elevations, obtained from the LIDAR data, with a square mesh of $1 \mathrm{~m}$ available in the Italian National Geoportal, with the run-up values reached by the storms of fixed return period, inclusive of the tidal excursion and of the sea water level rise (SWLR). Regarding the hazard mapping, which is congruent with the Flood Directive 2007/60/EC, in Scilla the port and numerous houses located in Chianalea are flooded annually. On the other hand, in Marina Grande the floods with annual frequency impact only the beach, which is almost completely flooded in the western part and only partially flooded in the remaining parts. The promenade of Marina Grande and its houses are however flooded from events with a return period of 20 years while events with a return period of 100 years flood the whole town. Regarding Monasterace, only events with a return period of 100 years reach the promenade and the houses. The floods with shorter return period affect only the beach and the foot of the dune on which the archaeological site is located.

For damage maps, the damage assessment followed an "ex ante" approach, based on the employment of land use maps, and in accordance with the current Italian legislation. Furthermore, the input data were those available in the OpenData section of the Calabrian Geoportal. In particular, the shapefiles of the land use were analyzed and the potential damage classes, from D1 to D4, in increasing damage), are in agreement with the Flood Directive 2007/60/EC. These classes depend mainly on damage to people, and then on socioeconomic and non-monetizable assets. With reference to damage mapping, in both locations the flood areas fall into damage classes D1 and D4. In the D1 class the beaches are included, while in the D4 class there are the houses, promenades, state roads and the port of Scilla and the archaeological site of Monasterace.

Concerning the risk maps, they were been obtained by combining hazard and damage maps. In Scilla an area of over
$115,000 \mathrm{~m}^{2}$ is at risk. Moreover, almost 200 houses, 10 bathing establishments, the entire promenade, the road connecting the promenade and the port and a part of the state road (a road length of over 1,000 $\mathrm{m}$ in total) are at risk. In Monasterace, however, the area at risk has an extension of about $65,000 \mathrm{~m}^{2}$. In addition, 31 houses and a part of the promenade are also at risk, for a road length of about $650 \mathrm{~m}$.

This paper applies existing methodologies to map the hazard, damage and risk areas of two locations which are particularly prone to coastal flooding. The comparison with previous events allowed us to verify the validity of these methodologies. Finally, the mapping described in this paper can be used both to choose appropriate mitigation measures and to plan and manage coastal flooding areas.

\section{ACKNOWLEDGMENT}

The authors wish to thank Ing. Vito Nardi for his very helpful support in the development of the Matlab code used.

\section{REFERENCES}

[1] Syvitski, J.P.M., Vorosmarty, C.J., Kettner, A.J., Green, P. (2005). Impact of humans on the flux of terrestrial sediment to the global coastal ocean. Science, 308(5720): 376-380. https://doi.org/10.1126/science.1109454

[2] European Union (2012). Sustainable tourism in the Mediterranean. Report. https://doi.org/10.2863/69472

[3] Komar, P.D. (2000). Coastal erosion-underlying factors and human impacts. Shore \& Beach, 68(1): 3-16.

[4] Boak, E.H., Turner, I.L. (2005). Shoreline definition and detection: A review. Journal of Coastal Research, 21(4): 688-703. https://doi.org/10.2112/03-0071.1

[5] Foti, G., Sicilia, C.L. (2013). Analysis, evaluation and innovative methodologies to prevent coastal erosion. WIT Transaction on Ecology and the Environment, 169: 219-230. https://doi.org/10.2495/cp130191

[6] Barbaro, G., Fiamma, V., Barrile, V., Foti, G., Ielo, G. (2017). Analysis of the shoreline changes of Reggio Calabria (Italy). International Journal of Civil Engineering and Technology, 8(10): 1777-1791.

[7] Fiori, E., Comellas, A., Molini, L., Rebora, N., Siccardi, F., Gochis, D.J., Tanelli, S., Parodi, A. (2014). Analysis and hindcast simulations of an extreme rainfall event in the Mediterranean area: The Genoa 2011 case. Atmospheric Research, 138: 13-29. https://doi.org/10.1016/j.atmosres.2013.10.007

[8] Barbaro, G., Foti, G., Sicilia, C.L. (2014). Coastal erosion in the South of Italy. Disaster Advances, 7: 3742.

[9] Barbaro, G. (2016). Master Plan of solutions to mitigate the risk of coastal erosion in Calabria (Italy), a case study. Ocean \& Coastal Management, 132: 24-35. https://doi.org/10.1016/j.ocecoaman.2016.08.001

[10] Barbaro, G., Petrucci, O., Canale, C., Foti, G., Mancuso, P., Puntorieri, P. (2019) Contemporaneity of floods and storms. A case study of Metropolitan Area of Reggio Calabria in Southern Italy. Smart Innovation, Systems and Technologies, 101: 614-620. https://doi.org/10.1007/978-3-319-92102-0_66

[11] Li, N., Yamazaki, Y., Roeber, V., Cheung, K.F., Chock, G. (2018). Probabilistic mapping of storm-induced 
coastal inundation for climate change adaption. Coastal Engineering, 133: 126-141. https://doi.org/10.1016/j.coastaleng.2017.12.013

[12] Scionti, F., Miguez, M.G., Barbaro, G., De Sousa, M.M., Foti, G., Canale, C. (2018). An integrated methodology for urban flood risk mitigation: The case study of Cittanova (Italy). Journal of Water Resources Planning and Management, 144(10). https://doi.org/10.1061/(ASCE)WR.1943-5452.0000985

[13] Barbaro, G., Foti, G., Sicilia, C.L. (2013). Wave forces on upright breakwater, evaluation and case study. Disaster Advances, 6: 90-95.

[14] Miduri, M., Foti G., Puntorieri P. (2017). Impact generated by Marina of Badolato (Italy) on adjacent coast Proceeding of 13th International Congress on Coastal and Marine Sciences, Engineering, Management and Conservation MEDCOAST (Mellieha, Malta).

[15] Barbaro, G., Foti, G., Miduri, M., Puntorieri, P. (2019). Shoreline changes caused by Marina of Badolato (Italy). International Journal of Civil Engineering and Technology, 10(7): 298-307. Article ID: IJCIET_10_07_030.

[16] Holman, R.A. (1986). Extreme value statistics for wave run-up on a natural beach. Coastal Engineering, 9(6): 527-544. https://doi.org/10.1016/0378-3839(86)90002-5

[17] Rahman, A.F., Dragoni, D., El-Masri, B. (2011). Response of the Sundarbans coastline to sea level rise and decreased sediment flow: A remote sensing assessment. Remote Sensing of Environment, 115(12) 3121-3128. https://doi.org/10.1016/j.rse.2011.06.019

[18] Barbaro, G., Foti, G., Malara, G. (2011). Set-up due to random waves: influence of the directional spectrum. Proceedings of the 30th International Conference on Ocean, Offshore and Artic Engineering OMAE (Rotterdam, The Netherlands), 6: 789-797. https://doi.org/10.1115/OMAE2011-49977

[19] Barbaro, G., Foti, G., Mandaglio G., Mandaglio, M., Sicilia, C.L. (2012). Estimate of sediment transport capacity in the basin of the Fiumara Annunziata (RC). Rendiconti Online Società Geologica Italiana, 21(1): 696-697.

[20] Sicilia, C.L., Foti, G., Campolo, A. (2013). Protection and management of the Annunziata river mouth area (Italy). Journal of Air, Soil and Water Research, 6: 107113. https://doi.org/10.4137/ASWR.S13143

[21] Barbaro, G., Foti, G., Sicilia, C.L., Malara, G. (2014). A formula for the calculation of the longshore sediment transport including spectral effects. Journal of Coastal Research, 30 : 961-966 https://doi.org/10.2112/JCOASTRES-D-13-00131.1

[22] Tomasicchio, G.R., D'Alessandro, F., Barbaro, G., Musci, E., De Giosa, T.M. (2015) Longshore transport at shingle beaches: An independent verification of the general model. Coastal Engineering, 104: 69-75. https://doi.org/10.1016/j.coastaleng.2015.07.003

[23] Yang, Z., Wang, T., Voisin, N., Copping, A. (2015). Estuarine response to river flow and sea-level rise under future climate change and human development. Estuarine, Coastal and Shelf Science, 156: 19-30. https://doi.org/10.1016/j.ecss.2014.08.015

[24] Borrello, M.M., Foti G., Puntorieri P. (2017). Shoreline evolution near the mouth of the Petrace River (Reggio Calabria, Italy). WIT Transaction on Ecology and The Environment, 221:

59-67. https://doi.org/10.2495/rbm170071

[25] Barbaro, G., Bombino, G., Foti, G., Borrello, M.M., Puntorieri, P. (2019). Shoreline evolution near river mouth: Case study of Petrace River (Calabria, Italy). Regional Studies in Marine Science, 29. https://doi.org/10.1016/j.rsma.2019.100619

[26] Emilia-Romagna Region. (2013). Mappe della pericolosità e del rischio di alluvione. Distretto Appennino Settentrionale - Ambito Marino-Costiero. [in Italian].

[27] Leal, M., Ramos, C. (2017). The potential of two types of urban flooding to cause material damages in Lisbon, Portugal. International Journal of Safety and Security Engineering, 7(2): 190-200. https://doi.org/10.2495/safev7-n2-190-200

[28] Adedeji, T.J., Proverbs, D.G., Xiao, H., Oladokun, V.O. (2018). Towards a conceptual framework for property level flood resilience. International Journal of Safety and Security Engineering, 8(4): 493-504. https://doi.org/10.2495/safe-v8-n4-493-504

[29] Sartor, J., Mobilia, M., Longobardi, A. (2018). Results and findings from 15 years of sustainable urban storm water management. International Journal of Safety and Security Engineering, 8(4): 505-514. https://doi.org/10.2495/safe-v8-n4-505-514

[30] Jimenez, J.A. (2009). Guidelines on coastal flood hazard mapping. T03-08-02. (FLOOD SITE).

[31] Zanuttigh, B. (2011). Coastal flood protection: what perspective in a changing climate? The THESEUS approach. Environmental Science \& Policy, 14(7): 845863. https://doi.org/10.1016/j.envsci.2011.03.015

[32] Liguria Region (2014). Mappatura della pericolosità da inondazione marina nelle aree costiere della regione Liguria. [in Italian].

[33] Perini, L., Calabrese, L., Salerno, G., Ciavola, P., Armaroli, C. (2016). Evaluation of coastal vulnerability to flooding: comparison of two different methodologies adopted by the Emilia-Romagna region (Italy). Natural Hazards and Earth System Sciences, 16(1): 181-194. https://doi.org/10.5194/nhess-16-181-2016

[34] Martinez-Grana, A.M., Boski, T., Goy, J.L., Zazo, C., Dabrio, C.J. (2016). Coastal-flood risk management in central Algarve: Vulnerability and flood risk indices (South Portugal). Ecological Indicators, 71: 302-316. https://doi.org/10.1016/j.ecolind.2016.07.021

[35] Di Risio, M., Bruschi, A., Lisi, I., Pesarino, V., Pasquali, D. (2017). Comparative analysis of coastal flooding vulnerability and hazard assessment at national scale. Journal of Marine Science and Engineering, 5(4): 51. https://doi.org/10.3390/jmse5040051

[36] Ferreira Silva, S., Martinho, M., Capitao, R., Reis, T., Fortes, C.J. Ferreira, J.C. (2017). An index-based method for coastal-flood risk assessment in low-lying areas (Costa de Caparica, Portugal). Ocean \& Coastal Management, 144: 90-104. https://doi.org/10.1016/j.ocecoaman.2017.04.010

[37] Jaranovic, B., Trindade, J., Ribeiro, J., Silva, A. (2017). Using a coastal storm hazard index to assess storm impacts in Lisbon. International Journal of Safety and Security Engineering, 7(2): 221-233. https://doi.org/10.2495/safe-v7-n2-221-233

[38] De Angeli, S., D'Andrea, M., Cazzola, G., Dolia, D., Duo, E., Rebora, N. (2018). Coastal Risk Assessment Framework: Comparison of modelled fluvial and marine 
inundation impacts, Bocca di Magra, Ligurian coast, Italy. Coastal Engineering, 134: 229-240. https://doi.org/10.1016/j.coastaleng.2017.09.011

[39] Lemee, C., Fleury-Bahi, G., Krien, N., Dededalle, A., Mercier, D., Coquet, M., Rommel, D., Navarro, O. (2018). Factorial structure of the coastal flooding risk perception and validation of a French coastal flooding risk evaluation scale (CFRES) for non-experts. Ocean \& Coastal Management, 155: 68-75. https://doi.org/10.1016/j.ocecoaman.2018.01.030

[40] Burby, R.J. (1998). Cooperating with Nature: Confronting Natural Hazards with Land-use Planning for Sustainable Communities. Joseph Henry Press, Washington DC, USA, 1998.

[41] NAP. (1999). Impacts of Natural Disasters: A Framework for Loss Estimation. National Academy Press, Washington DC, USA.

[42] Mileti, D.S. (1999). Disasters by Design: A Reassessment of Natural Hazards in the United States. Joseph Henry Press, Washington DC, USA.

[43] Barredo, J.I., Salamon, P., Bódis, K. (2008). Towards an assessment of coastal flood damage potential in Europe. European Commission, Joint Research Centre (JRC) and Institute for Environment and Sustainability (IES), EUR, 23698.

[44] Parker, D.J., Green, C.H., Thompson, P.M. (1987). Urban Flood Protection Benefits-A Project Appraisal Guide. Gower Technical Press, UK.

[45] Dutta, D., Herath, S., Musiake, K. (2003). A mathematical model for flood loss estimation. Journal of Hydrology, 277(1-2): 24-49. https://doi.org/10.1016/S0022-1694(03)00084-2

[46] Penning-Rowsell, E.C., Chatterton, J.B. (1977). The benefits of flood alleviation: A manual of assessment techniques.

[47] Thieken, A.H., Olschewski, A., Kreibich, H., Kobsch, S., Merz, B. (2008). Development and evaluation of FLEMOps-a new flood loss estimation MOdel for the private sector. WIT Transactions on Ecology and the Environment, 118: 315-324. https://doi.org/10.2495/friar080301

[48] DIRECTIVE 2007/60/EC OF THE EUROPEAN PARLIAMENT AND OF THE COUNCIL on the assessment and management of flood risks. (2007). Official Journal of the European Union, L 288/27 L288/34.

[49] Italian Environmental Ministry. (2010). Indirizzi operativi per l'attuazione della direttiva 2007/60/CE relativa alla valutazione ed alla gestione dei rischi da alluvioni con riferimento alla predisposizione delle mappe della pericolosità e del rischio di alluvioni (D.Lgsl.49/2010). [in Italian].

[50] Nucera, A., Foti, G., Canale, C., Puntorieri, P., Minniti, F. (2018). Coastal flooding: damage classification and

case studies in Calabria (Italy). WIT Transactions on Engineering Sciences, 121: 93-103. https://doi.org/10.2495/RISK180081

[51] Stockdon, H.F., Holman, R.A., Howd, P.A., Sallenger, A.H.J. (2006). Empirical parameterization of setup, swash, and runup. Coastal Engineering, 53(7): 573-588. https://doi.org/10.1016/j.coastaleng.2005.12.005

[52] Boccotti, P. (2015). Wave mechanics and wave loads on marine structures. Elsevier BH: Oxford (UK). https://doi.org/10.1016/c2013-0-13663-x

[53] Sannino, G., Carillo, A., Pisacane, G., Naranjo, C. (2015). On the relevance of tidal forcing in modeling the Mediterranean thermohailine circulation. Progress in Oceanography, 134: 304-329. https://doi.org/10.1016/j.pocean.2015.03.002

[54] Nerem, R.S., Beckley, B.D., Fasullo, J.T., Hamlington, B.D., Masters, D., Mitchum, G.T. (2018). Climatechange-driven accelerated sea-level rise detected in the altimeter area. Proceedings of the National Academy of Sciences of the United States of America, 115(9): 20222025. https://doi.org/10.1073/pnas.1717312115

[55] IPCC. (2013). Climate Change 2013: The Physical Science Basis. Contribution of Working Group I to the Fifth Assessment Report of the Intergovernmental Panel on Climate Change. In: Stocker, T.F., D. Qin, G.-K. Plattner, M. Tignor, S.K. Allen, J. Boschung, A. Nauels, Y. Xia, V. Bex and P.M. Midgley (eds) Cambridge University Press, Cambridge, United Kingdom and New York, NY, USA.

\section{NOMENCLATURE}

$\mathrm{u}$

W

$\mathrm{a}_{10}$

$b_{10} \quad$ average value of triangular storm bases equivalent to the real storms, referring to a sample of the $\mathrm{N}$ stronger real storm, with $\mathrm{N}$ equal to 10 for the number of years of registration $\mathrm{h}$

$\mathrm{H}_{\mathrm{s}, \max }$ maximum significant height of a real storm, $\Delta \mathrm{t}$

dimensionless parameter that describes a Weibull-type distribution of the probability of exceeding a fixed significant height threshold

parameter that describes a Weibull-type distribution of the probability of exceeding a fixed significant height threshold, $\mathrm{m}$ average value of triangular storm heights equivalent to the real storms, referring to a sample of the $\mathrm{N}$ stronger real storm, with $\mathrm{N}$ equal to 10 for the number of years of registration, $\mathrm{m}$

$\mathrm{m}$

duration of a real storm, $h$ 